\title{
Penurunan Tingkat Kecemasan Anak Melalui Terapi Bermain di RumKital Dr. Midiyato Suratani Tanjungpinang
}

\author{
Wasis Pujiati*1, Hotmaria Julia Dolok Saribu², Zakiah Rahman ${ }^{3}$, Syamilatul Khariroh ${ }^{4}$ \\ 1,2,3,4Program Studi S1 Keperawatan Stikes Hang Tuah Tanjungpinang \\ *e-mail: wasispujiati82@gmail.com ${ }^{1}$.hotmariajuliads@gmail.com ${ }^{2}{ }_{2}$ faizazka2@gmail.com $^{3}{ }_{2}$
} khariroh65@gmail.com ${ }^{4}$

Nomor Handphone Untuk keperluan koordinasi : 0813-8576-8248

\begin{abstract}
Abstrak
Kecemasan merupakan suatu keadaan emosional yang tidak menyenangkan yang ditandai oleh rasa ketakutan dan gejala fisik yang menegangkan dan tidak diinginkan oleh anak, sehingga akan berpengaruh pada kesehatannya. Tujuan kegiatan ini adalah menurunkan kecemasan pada anak yang sedang di rawat di Rumah Sakit yaitu dengan mengadakan kegiatan terapi bermain. Metode yang digunakan oleh Tim Pengabdian adalah dengan terapi bermain mewarnai. Terapi bermain merupakan salah satu asuhan keperawatan pada anak untuk mengurangi kecemasan dan ketakutan. Berdasarkan studi pendahuluan pada tanggal 14 Oktober 2019 dan data rekam medik di Rumkital Dr. Midiyato Suratani Tanjungpinang didapatkan data jumlah kunjungan pada anak usia 3-5 tahun dari bulan Juli- September 2019 sebanyak 120 orang anak. Pada saat terapi bermain anak yang dilakukan perawatan sebanyak 10 orang dengan kriteria anak prasekolah. Hasil pretest menunjukkan anak dengan cemas sedang sebanyak 8 orang dan berat 2 orang setelah dilakukan terapi bermain terjadi penurunan menjadi cemas ringan sebanyak 9 orang dan cemas sedang 1 orang. Terapi bermain di Ruang Anak ini memang harus diberikan supaya anak yang dirawat mampu mengatasi kecemasan dan ketakutan yang dialami selama masa dirawat di Rumah sakit (hospitalisasi).
\end{abstract}

Kata kunci: cemas, anak sekolah, hospitalisasi, terapi bermain

\begin{abstract}
Anxiety is an unpleasant emotional state characterized by fear and physical symptoms that are stressful and unwanted by children, so that it will affect their health. The purpose of this activity is to reduce anxiety in children who are being treated at the hospital, namely by holding play therapy activities. The method used by the Devotion Team is coloring play therapy. Play therapy is one of the nursing care for children to reduce anxiety and fear. Based on a preliminary study on 14 October 2019 and medical record data at Rumkital Dr. Midiyato Suratani Tanjungpinang obtained data on the number of visits to children aged 3-5 years from July-September 2019 as many as 120 children. At the time of play therapy, 10 people were treated with preschool children criteria. The results of the pretest showed that there were 8 children with moderate anxiety and 2 people with heavy anxiety after playing therapy there was a decrease to 9 people with mild anxiety and 1 person with moderate anxiety. Play therapy in the Children's Room should indeed be given so that the treated child is able to overcome the anxiety and fear experienced during the hospitalization period (hospitalization)..
\end{abstract}

Keywords: anxiety, school children, hospitalization, play therapy

\section{PENDAHULUAN}

Berdasarkan dari hasil study pendahuluan yang dilakukan pada tanggal 14 Oktober 2019 dan hasil data rekaman medik di Rumkital Dr. Midiyato Suratani Tanjungpinang, didapatkan jumlah kunjungan pada anak usia 3-5 tahun dari bulan Juli-September 2019 sebanyak 120 orang anak. Berdasarkan hasil wawancara dengan kepala Ruang Anak (Subi Kecil) bahwa di RSAL sudah memiliki ruang bermain untuk anak yang dilakukan perawatan akan tetapi terapi berman belum kontinyu dilakukan, hanya jika ada mahasiswa praktik di ruangan tersebut maka terapi bermain dilakukan karena merupakan salah satu tugas dari mahasiswa pada keperawatan anak dan berdasarkan pengamatan beberapa orang tua membawa mainan ketempat tidur anaknya agar anak merasa lebih nyaman. Hasil dari wawancara yang dilakukan dengan salah seorang 
dari orang tua anak mengatakan bahwa anaknya selama kurang lebih 2 hari dirawat di ruang Subi terjadi perubahan seperti anak sering rewel, anak mudah menangis, tidak bisa jauh dari ibunya, dan sulit untuk diberikan makan dan anaknya sering terbangun dan susah untuk tidur kembali.

Rumkital Dr Midiyato Suratani Tanjungpinang merupakan rumah sakit milik angkatan laut, jarak tempuh perjalanan sekitar 25 menit dari Stikes Hang Tuah Tanjungpinang, dimana berdasarkan observasi Hospitalisasi, baik itu hospitalisasi jangka pendek, pembedahan, ataupun hospitalisasi jangka panjang dari suatu penyakit yang kronik sering kali menjadi krisis pertama yang harus dihadapi anak, terutama selama tahun-tahun awal. Hal ini sering menimbulkan stres karena anak akan mengalami ketakutan terhadap orang asing yang tidak dikenalnya dan pekerja rumah sakit, perpisahan dengan orang terdekat, kehilangan kendali, ketakutan tentang tubuh yang disakiti, dan nyeri [1]. Reaksi-reaksi tersebut dipengaruhi oleh usia perkembangan; pengalaman sebelumnya dengan penyakit, perpisahan,atau hospitalisasi; keterampilan koping yang dimiliki; keparahan diagnosis; dan sistem pendukung yang ada [2].

Hospitalisasi juga menimbulkan beberapa dampak pada anak di antaranya seperti dampak perpisahan, kehilangan kontrol, sakit/nyeri, dan beberapa akibat dari dampak hospitalisasi tersebut ialah anak merasa putus asa, menimbulkan reaksi protes, tidak kooperatif, depresi. Ada beberapa faktor yang mempengaruhi cemas pada anak yang dirawat dirumah sakit, antara lain: akibat perubahan status kesehatan maupun lingkungan dalam kebiasaan seharihari, keterbatasan dalam mekanisme koping untuk mengatasi masalah maupun kejadiankejadian yang bersifat menekan [3]. Hospitalisasi seringkali menciptakan peristiwa traumatik dan penuh stress bagi anak dan keluarga, baik itu merupakan prosedur efektif yang telah direncanakan sebelumnya ataupun akan situasi darurat yang terjadi akibat trauma. Stressor yang dapat dialami oleh anak terkait dengan hospitalisasi dapat menghasilkan berbagai reaksi. Anak bereaksi terhadap stres hospitalisasi sebelum masuk, selama hospitalisasi, dan setelah pulang. Selain efek fisiologis masalah kesehatan, efek hospitalisasi pada anak mencakup ansietas serta ketakutan, ansietas perpisahan dan kehilangan kontrol [4].

Cemas akibat perpisahan atau yang biasa disebut depresi analitik, merupakan stress utama pada bayi usia pertengahan sampai usia prasekolah. Pada rentang usia tersebut kecemasan dimanifestasikan dalam tiga fase, yaitu fase protes, putus asa, dan pelepasan. Selama fase protes, anak-anak bereaksi secara agresif, menolak perhatian dari orang lain, dan kedukaan mereka tidak dapat ditenangkan. Selama fase putus asa, anak-anak cenderung tidak aktif, tidak tertarik, dan menarik diri dari orang lain. Sedangkan fase pelepasan, anak akan tampak menyesuaikan diri terhadap lingkungan, akan tetapi hal ini merupakan hasil dari kepasrahan dan bukan merupakan tanda-tanda kesenangan [2].

Tujuan utama asuhan keperawatan anak yang dihospitalisasi adalah meminimalkan munculnya masalah pada perkembangan anak. Perawat yang melibatkan anak dalam aktivitas yang sesuai dengan tingkat perkembangan akan lebih menormalkan lingkungan anak dan membantu mengurangi gangguan perkembangan anak [3]. Bermain merupakan pekerjaan pada masa kanak-kanak. Ahli pekembangan anak mengakui bahwa bermain sebagai strategi koping yang penting bagi anak, hal tersebut merupakan aspek terpenting dalam kehidupan anak serta merupakan salah satu cara yang paling efektif menurunkan stres pada anak dan penting untuk menyejahterakan mental dan emosional anak [5].

Terapi Bermain merupakan suatu aktivitas dimana anak dapat melakukan atau mempraktikkan ketrampilan, memberikan ekspresi terhadap pemikiran, menjadi kreatif, mempersiapkan diri untuk berperan dan berperilaku dewasa [6]. Ada beberapa fungsi bermain di rumah sakit antara lain: mengenalkan pada anak pada lingkungan dan keadaan yang asing, mengajarkan untuk bisa membuat keputusan dan kontrol, untuk mengurangi stress dan cemas, untuk mengurangi nyeri, mengenalkan tentang tujuan dan penggunaan alat medis [3].

Bermain dapat dijadikan sebagai suatu terapi karena berfokus pada kebutuhan anak untuk mengekspresikan diri mereka melalui penggunaan mainan dalam aktivitas bermain dan dapat digunakan untuk membantu anak mengerti tentang penyakitnya. Bermain terapeutik sudah diidentifikasi sebagai intervensi yang efektif untuk persiapan anak hospitalisasi, koping, pemahaman, dan prosedur untuk mengurangi nyeri, dan stress karena hospitalisasi. Prosesnya 
dapat dilakukan dengan cara melibatkan penggunaan film, video, atau buku-buku [7]. Mainan adalah 'alat' bermain dan memberikan lingkungan yang lebih 'alami' untuk anak. Pemilihan dan penggunaan mainan yang tepat dapat mengurangi efek traumatis dari pengalaman rawat inap dan membantu dalam fase pemulihan penyakit. Penelitian menemukan adanya pengaruh terapi bermain terhadap tingkat kekooperatifan pada anak usia 3-5 tahun [8]. Terapi bermain berdampak terhadap penurunan kecemasan perpisahan pada anak prasekolah yang mengalami hospitalisasi [5]. Hasil penelitian terdahulu membuktikan bahwa terapi menggambar dan mewarnai gambar mampu menurunkan kecemasan pada anak [9]. Terapi bermain (mewarnai) efektif terhadap penurunan kecemasan akibat hospitalisasi pada anak usia pra sekolah (3-6 tahun) [10].

Mewarnai gambar memberikan dampak yang positif pada anak, dimana kegiatan mewarnai gambar dapat memberikan efek rileks pada responden karena aktivitasnya yang mengasikkan dimana anak mengenali gambar dan memilih warna yang yang cocok untuk diberikan pada gambar tersebut. Terapi bermain mewarnai sangat membantu anak mengatasi tingkat kecemasan yang sangat berlebihan dan sangat baik untuk beradaptasi dengan lingkungan sekitarnya dan suasana teman baru bahkan dengan team medis dalam pemberian obat.

Berdasarkan uraian diatas Tim pengabdian bersepakat melakukan pengabdian masyarakat di Ruang Rawat Inap Anak Subi Kecil RSAL Dr.Midiyato Suratani Tanjungpinang untuk mengurangi dampak hospitalisasi pada anak yang menjalani perawatan dengan menggunakan intervensi keperawatan terapi bermain.

\section{METODE}

Kegiatan pengabdian masyarakat ini berupa terapi bermain dengan mewarnai gambar dilakukan oleh tim pengabdian bersama mahasiswa ners dan diberikan kepada anak-anak yang di rawat di Ruang Subi Kecil Rumkital Dr. Midiyato Tanjungpinang. Kegiatan ini dilaksanakan pada bulan Oktober tahun 2019. Sasaran dalam kegiatan ini adalah anak-anak yang sakit dan di rawat di Ruang Subi Kecil. Adapun kontribusi sasaran dalam pengabdian masyarakat ini adalah anak-anak yang dirawat yang mengalami kecemasan diberikan terapi bermain mewarnai untuk menurunkan kecemasan selama dilakukan perawatan di Ruang Subi Kecil. berikut:

Tahapan pelaksanaan kegiatan pengabdian kepada masyarakat ini adalah sebagai

a. Kegiatan awal/persiapan

1) Mengkaji dan menganalisis data

2) Mengidentifikasi masalah

3) Menyusun proposal kegiatan pengabdian kepada masyarakat

4) Menyusun SAP dan materi serta menyiapkan buku mewarnai beserta crayon yang akan diberikan kepada sasaran.

5) Menyiapkan lembar pre-test dan post-test tentang kecemasan anak selama di lakukan perawatan.

6) Mengurus izin lokasi pengabdian kepada masyarakat

b. Pelaksanaan kegiatan

1) Perkenalan antara tim pengabdian kepada masyarakat dengan sasaran

2) Penjelasan kegiatan yang akan dilakukan dalam melibatkan sasaran

3) Memberikan lembar pre-test

4) Memberikan satu persatu kepada anak buku mewarnai dan crayon

5) Memberikan lembar post-test

6) Penutupan dan pemberian bingkisan.

c. Penyusunan laporan dan publish jurnal pengabdian masyarakat

1) Merumuskan hasil pengabdian kepada masyarakat 
2) Mengumpulkan dokumentasi dan lampiran yang mendukung kegiatan (daftar hadir, fotofoto, dan surat-surat)

3) Menyerahkan laporan, Membuat jurnal pengabdian dan melakukan publish jurnal

\section{HASIL DAN PEMBAHASAN}

Berikut adalah data hasil pre tes dan post test Kegiatan terapi bermain. Kegiatan terapi di lakukan dengan tetap menyesuikan kapasitas ruangan bermain di Ruang Subi Kecil.

Tabel 1. Hasil pre tes anak sebelum terapi bermain

\begin{tabular}{ccc}
\hline Tingkat Kecemasan & F & Persen(\%) \\
\hline Ringan & & \\
Sedang & 8 & 80 \\
Berat & 2 & 20 \\
Total & 10 & 100 \\
\hline
\end{tabular}

Tabel 2. Hasil post tes anak setelah terapi bermain

\begin{tabular}{ccc}
\hline Tingkat Kecemasan & F & Persen(\%) \\
\hline Ringan & 9 & 90 \\
Sedang & 1 & 10 \\
Berat & 0 & 0 \\
Total & 10 & 100 \\
\hline
\end{tabular}

Dibawah adalah dokumentasi kegiatan terapi bermain mewarnai di Ruang Subi Kecil Rumkital Dr Midiyato Suratani Tanjungpinang

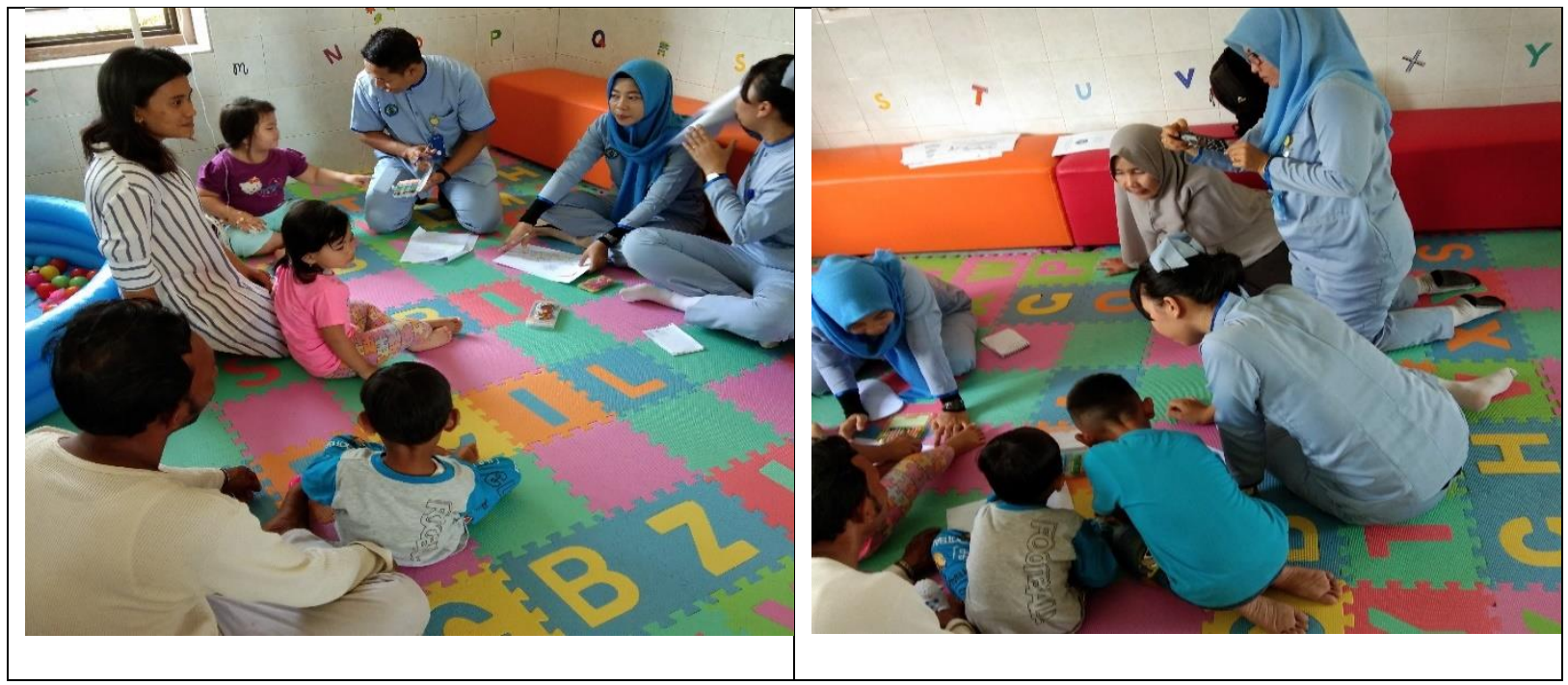

Gambar 1 dan 2: Kegiatan Terapi bermain di Ruang Subi Kecil Rumkital Dr Midiyato Suratani Tanjungpinang

Berdasarkan data yang didapatkan bahwa terdapat penurunan kecemaasan sedang 8 $(80 \%)$ dan berat 2 anak (20\%), setelah dilakukan terapi bermain mewarnai terjadi penurunan menjadi kecemasan ringan 9 orang (90\%) dan kecemasan sedang 1 anak (10\%).

Kami dosen ilmu keperawatan Sekolah Tinggi Ilmu Kesehatan Stikes Hang Tuah Tanjungpinang melakukan kegiatan terapi bermain mewarnai sebagai bentuk pengabdian kepada masyarakat, Terapi mewarnai gambar sendiri merupakan salah satu permainan yang sesuai dengan prinsip rumah sakit dimana secara psikologis permainan ini dapat membantu mengekspresikan perasaan pikiran cemas, takut, sedih, tertekan dan emosi. Selain itu pada usia 
prasekolah (3-6 tahun) tumbuh kembang anak berada dalam masa bermain dimana setiap waktu anak diisi dengan bermain, oleh karena itu terapi bermain sangat efektif diberikan pada usia ini karena sesuai dengan tingkatan usia anak. Kesan orang tua terhadap kegiatan ini adalah anak dan orangtua merasa senang karena anak mampu melupakan sejenak kecemasan yang dialami selama di rawat.

\section{KESIMPULAN}

Dampak hospitalisasi menjadikan anak cemas saat dilakukan perawatan di ruang rawat untuk itu diperlukannya suatu terapi untuk menurunkan kecemasan pada anak yaitu terapi bermain. Berdasarkan nilai pre test sebelum diberikan terapi bermain mewarnai anak yang mengalami kecemasan sedang sebanyak 8 orang $(80 \%)$ dan 2 orang (20\%) mengalami kecemasan berat, setelah diberikan terapi bermain terjadi penurunan, kecemasan ringan 9 orang $(90 \%)$ dan 1 orang anak dengan kecemasan sedang (10\%). Secara umum tingkat kecemasan anak mengalami cemas sedang dan berat dan setelah diberikan terapi bermain menjadi ringan dan terlihat anak nampak senang dan nyaman selama hospitalisasi. Ruangan anak perlu memfasilitasi untuk kegiatan terapi bermain minimal satu kali selama anak di lakukan perawatan untuk mengurangi kecemasan. Terapi bermain mewarnai ini sangat mudah untuk dilakukan dan tidak banyak memerlukan biaya.

\section{UCAPAN TERIMA KASIH}

Ucapan terimakasih disampaikan kepada Karumkital Dr Midiyato Suratani dan Perawat Ruang Subi Kecil yang telah bersedia memberikan fasilitas sehingga terselenggaranya kegiatan pengabdian masyarakat oleh Dosen Stikes Hang Tuah Tanjungpinang.

\section{DAFTAR PUSTAKA}

[1] Potter \& Perry. (2019). Buku Ajar Fundamental Keperawatan: Konsep Proses \& Praktek. Edisi 4, Vol. 1. Jakarta: EGC

[2] Hockenberry, M.J., \& Wilson, D. (2013). Wong's essentials of pediatrik nursing (9 tahun Ed.). St. Louis: Mosby).

[3] Donna L. Wong. ...... et all. 2008. Buku Ajar Keperawatan Pedriatik. Cetakan pertama. Jakarta : EGC.

[4] Kyle \& Carman. (2015). Buku Ajar Keperawatan Pediatri (Essetials of Pediatric Nursing). Volume 2. Edisi 2. Jakarta: EGC.

[5] Purwandari, H., Mulyono, W.A., \& Sucipto, A. (2010). Terapi bermain untuk menurunkan kecemasan perpisahan pada anak prasekolah yang mengalami hospitalisasi. Jurnal Keperawatan Profesional Indonesia, 52-59.

[6] Adriana Dian. (2011). Tumbuh Kembang \& Terapi Bermain Pada Anak, Jakarta : Salemba Medika.

[7] Alfiyanti, D., Hartiti, T., dan Samiasih, A., 2007, Pengaruh Terapi Bermain Terhadap Tingkat Kecemasan Anak Usia Prasekolah Selama Tindakan Keperawatan di Ruang Lukman Rumah Sakit Roemani Semarang, Jurnal Keperawatan., 1(1):35-44.

[8] Handayani, R., \& Puspitasari. (2009). Pengaruh terapi bermain terhadap tingkat kooperatif selama menjalani perawatan pada anak usia prasekolah (3-5 tahun) di Rumah Sakit Panti Rapih Yogyakarta. Jurnal Kesehatan Surya Medika.

[9] Rani Fitriani Arifin,. Udiyani R, Rini. (2019). Efektifitas terapi menggambar dan mewarnai gambar terhadap kecemasan hospitalisasi usia prasekolah (effectiveness of drawing and color in picture therapy of hospitalization anxiety in pre school age). Jurnal Darul Azhar Vol 6, No.1 Agustus 2018 - Januari 2019, Hal : 53 - 58 
[10] Muhamad Idris, Mathilda Reza. (2018). Efektifitas terapi bermain (mewarnai) terhadap penurunan kecemasan akibat hospitalisasi pada anak usia prasekolah) (3-6 tahun) di Ruang Melati RSUD Kota Bekasi. Jurnal Afiat vol.4 no.2 tahun 2018 "kesehatan jiwa. 